\title{
Microhabitat Relationships of Six Major Shrubs in Navajo National Monument, Ari-
} zona

\author{
JOHN A. FAIRCHILD AND JACK D. BROTHERSON
}

\begin{abstract}
Six shrub species were studied to determine their microhabitat relationships as well as their effect on the immediate environment. Analysis of site characteristics and mineral composition of soils in open areas adjacent to shrubs and beneath shrubs allowed for comparison of the different habitats following shrub establishment. Soil pH differs beneath the various shrubs and all six species tended to create more alkaline soils beneath their canopy. All species showed increased soil salinity beneath their canopy. However, the concentration of total soluble salts in the soil surface beneath the shrubs varied with the species and was highest beneath fourwing saltbush. Significant increases in the concentration of magnesium and potassium ions beneath shrubs were observed. Nitrogen and phosphorus were also found in greater concentration beneath the shrub canopy. Soil depth differed beneath the shrub species, with sagebrush and fourwing saltbush growing on the deeper more highly developed types. There was a positive relationship between the presence of shrubs and the depth of the soil profile.
\end{abstract}

It has long been known that shrubs influence the soil characteristics beneath their canopy (Fireman and Hayward 1952). Studies done in the last decade show that shrubs influence both the horizontal and vertical patterning of soil chemicals (Charley and West 1975). Sharma and Tongway (1973) studied the effects of two species of saltbush (Atriplex nummularia and Atriplex vesicaria) on soil salinity and related properties. They recognized an accumulation zone beneath the shrubs, a zone of compensation where leaching of minerals replaced those absorbed, and a depletion zone from which mineral absorption exceeded the rate of replacement. Salt accumulation under shrubs, therefore, represents a redistribution of salts from peripheral regions of root activity (Charley and West 1975).

Plants employ several "strategies" for the removal of mineral wastes. Leaching of minerals from leaves is accomplished when the solution of the leaf surface connects with that of the intercellular spaces of the mesophyll and ions are lost by diffusion. Salts are also excreted with the aid of salt glands, as is the case with many Atriplex species. Salts are also concentrated in the extracellular spaces of leaves during the process of transpiration, thus accumulating minerals in leaves. Leaf fall subsequently serves as a mechanism for the elimination of mineral wastes (Epstein 1972).

Charley and West (1975) used the distributional patterns of carbon and nitrogen under and between shrubs as a measure of

\footnotetext{
Authors are range conservationist, Utah Division of Wildlife Resources, 1596 West North Temple, Salt Lake City, Utah 84116; and associate professor of botany and rangc science, Brigham Young University, Provo, Utah 84602.

Manuscript received November 27, 1978.
}

the soil organic pool. They showed that as precipitation increases, the average depth of soil wetting improves and so does the overall concentration of soil organic matter beneath shrubs. The mineral concentration in the soil surface layer was found to be the best indicator for the patterns observed.

Harner and Harper (1973) dealt with the increase in mineral concentration of vegetation along a moisture gradient and concluded that soil moisture allows for greater solubility and, therefore, greater absorption of minerals in more productive sites.

A few papers have treated the effect of mineral enrichment beneath shrubs on the productivity of associated grasses. Tiedeman and Klemmedson (1973) reported that beneath mesquite trees (Prosopis juliflora) the nutrient availability was elevated and accounted for significantly increased yields of Arizona cottontop (Trichachne californica) and plains bristlegrass (Setaria macrostachys). Rickard, et al., (1973) showed greasewood (Sarcobatus vermiculatus) and spiny hopsage (Grayia spinosa) induce predictable changes in mineral composition of soil and create more favorable conditions for production of cheatgrass (Bromus tectorum).

The purpose of this study was to compare the interaction of six species of shrubs with their immediate environment, the shrubs' general influence on their microhabitat, and the mincral content of the shrubs' foliage relative to their uptake patterns.

\section{Study Area}

Navajo National Monument is located in northeastern Arizona about 16 kilometers north and west of Black Mesa, Navajo County, Arizona. The monument headquarters are located on the Shonto Plateau near the head of Betatakin Canyon, a small side canyon of the Tsegi Canyon. The principal features of the monument are three large cliff dwellings of the Anasazi culture. Betatakin and Keet Seel are located in the Tsegi Canyon complex, while Inscription House is located in Nitsin Canyon, a branch of Navajo Canyon.

All three units typify a pinyon-juniper slickrock environment. Average annual temperature at Navajo National Monument headquarters is $10^{\circ} \mathrm{C}$. Yearly maximum temperatures range from $32^{\circ}$ to $38^{\circ} \mathrm{C}$ with an average of $36^{\circ} \mathrm{C}$; yearly low temperatures range from $-23^{\circ}$ to $-13^{\circ} \mathrm{C}$ with an average of $-17^{\circ} \mathrm{C}$. The frost-free season ranges from 107 to 213 days with an average of 155 days.

Total annual precipitation at Betatakin has historically ranged from a low of 17 centimeters to a high of 48 centimeters, with an average of 29 centimeters. The period of greatest precipitation is late summer and early fall. Most storms are localized and convectional in nature and, therefore, of high intensity and spotty distribution. This reduced and unpredictable rainfall, so characteristic of arid rangelands, has a profound effect on plant production and also mineral cycling (Charley 1977). 
Navajo Sandstone is the major geological formation in each of the three units. At Keet Seel and Inscription House, the Navajo Sandstone is the only exposed rock formation. At Betatakin, the Kayenta formation outcrops beneath the Navajo Sandstone and can be observed in the lower reaches of the canyon. In all three canyons the Navajo Sandstone forms tall, sheer cliffs up to 225 meters in height. At the base of these cliffs, tallus accumulations occur and the canyon bottoms are filled with deep deposits of sandy alluvium.

\section{Methods}

Three shrub-dominated communities were found on the rim of Betatakin Canyon. Big sagebrush (Artemisia tridentata) dominated the mesa above the canyon where the soil was well developed. A mixed-shrub community composed of cliff fendlerbush (Fendlera rupicola) was found occupying primarily the sloping terrain below the mesa and was characterized by rugged, tallus-like topography and shallow soils. Needle-leaf mountain mahogany (Cercocarpus intricatus) was restricted to the slickrock areas and appears to function in soil development and the establishment of islands of vegetation. Four-winged saltbush (Atriplex canescens) was found on tallus slopes and sandy alluvium above the streambed in Keet Seel Canyon. In order to avoid sampling heavily grazed areas, all plots were established within the fenced boundary of the park.

Line transects (one per species) were established for each shrub type. The placement of transects were biased in order to sample areas of optimal habitat for a study species. At 15-meter intervals along the transect the nearest individual (ten in all) of the species being sampled was centered in a plot that measured $4 \times 4$ meters. Each plot was subsampled with ten quadrats $\left(1 / 16 \mathrm{~m}^{2}\right)$ to determine vegetative cover of associated species. Composite soil samples were taken with a tubular soil probe to a depth of $15 \mathrm{~cm}$ underneath the shrub canopy and from adjacent open areas. In the mineral analysis only five of the ten composite soil samples were used. Plant samples included only current growth and were taken in mid-summer for all the shrubs to determine mineral composition. The following characteristics were recorded for each plot: exposure, percent slope, topographic position (ridgetop, midslope, or drainage accumulation area), and soil depth under and between the shrubs.

Soil samples were analyzed for texture (Bouyoucos 1951), pH, soluble salts, and mineral composition. Soil reaction was taken with a glass electrode $\mathrm{pH}$ meter. Total soluble salts were determined with a Beckman electrical conductivity bridge. A 1:1 soil-water paste (Russell 1948) was used to determine pH and total soluble salts. Soils were extracted with 1.0 normal ammonium acetate for the analysis of calcium, magnesium, potassium, and sodium. Zinc, manganese, iron, and copper were extracted from the soils with DPTA (diethylenetriaminepentaacetic acid). Ion concentrations were determined using a Perkin-Elmer Model 290 atomic absorption spectrophotometer. Soil phosphorus was extracted with sodium bicarbonate. Total nitrogen analysis was made using macrokjeldahl procedures (Jackson 1968).

Plant material was air-dried, ashed, and later analyzed for mineral composition by atomic absorption spectrophotometry.

\section{Results}

Measurements of canopy cover were taken for species associated with the different shrubs to determine if modification of the environment by the shrubs resulted in the establishment of distinct associations of plants (Table 1). Perhaps 16 of the 52 species sampled showed some degree of preference for one shrub habitat over the others. Since understory vegetation in pinyon-juniper communities is often sparse, it was expected that tree canopy also greatly influenced composition of the understory.

Cluster analysis (Sneath and Sokal 1973) was used to group shrub types that were similar with respect to the community composition of the various microhabitats (Fig. 1). Cliff
Table 1. Average percent cover for the important plant species of the six microhahits.

\begin{tabular}{|c|c|c|c|c|c|c|}
\hline \multirow[b]{2}{*}{ Species } & \multicolumn{6}{|c|}{ Site $^{a}$} \\
\hline & Cliff & Salt & Rose & Buff & Sage & Maho \\
\hline Amelanchier utahensis & & & & .02 & & \\
\hline Arabis perennans & .2 & & & & & $.19^{*}$ \\
\hline Artemisia frigida & & $1.45^{*}$ & & & & .15 \\
\hline Artemisia ludoviciana & & .04 & & .02 & & \\
\hline Artemisia tridentata & & .04 & $.90^{*}$ & . .78 & $9.24 *$ & \\
\hline Astragalus mollissimus & & & & & & .02 \\
\hline Atriplex canescens & & $10.72 *$ & & & & \\
\hline Bouteloua gracilis & $1.80^{*}$ & $2.64 *$ & $2.47 *$ & & $2.06^{*}$ & $2.39^{*}$ \\
\hline Bromus tectorum & & $1.50^{*}$ & & & & \\
\hline Cercocarpus intricatus & & & & & & $27.36^{*}$ \\
\hline Chrysothamnus nauseosus & & $.17^{*}$ & & & & .18 \\
\hline Cowania mexicana & 1.15 & & $17.67 *$ & $2.18^{*}$ & & \\
\hline Cryptantha flava & & .15 & .15 & & .05 & \\
\hline Descurainia sophia & & & .02 & & & \\
\hline Echinocactus fendleri & & & .32 & & & .98 \\
\hline Ephedra viridis & & .37 & .30 & 1.35 & & .15 \\
\hline Erigeron concinnus & .06 & & & & & \\
\hline Eriogonum microthecum & & .30 & & & & \\
\hline Eriogonum umbellatum & & & & & .15 & \\
\hline Erysimum asperum & .02 & & .04 & & .04 & $.31 *$ \\
\hline Fendlera rupicola & $16.99 *$ & .02 & & $2.88 *$ & & .98 \\
\hline Vulpia octaflora & .04 & .02 & $00.39 *$ & & & \\
\hline Gilia aggregata & & & & & $.22 *$ & \\
\hline Xanthocephalum sarothrae & $.54 *$ & $.92 *$ & $1.88 *$ & & & .30 \\
\hline Haplopappus nutallii & & & & .17 & & .15 \\
\hline Hymenopappus filifolius & & .15 & & & & \\
\hline Hymenoxys richardsoni & .02 & .32 & .05 & .26 & .02 & \\
\hline Juniperus osteosperma & .30 & & .02 & $6.72 *$ & 3.77 & \\
\hline Lappula redowskii & & .02 & .02 & & & \\
\hline
\end{tabular}

a Cliff fendlerbush, Salt $=$ Saltbush, Rose $=$ Cliffrose, Buff $=$ Buffaloberry,

Sage $=$ Sagebrush, Maho $=$ Mahogany

* Among the most prevalent species for the shrub type.

fendlerbush and buffaloberry communities were most similar in this respect although they were also similar to sagebrush and cliffrose. The plant understory associated with fourwing saltbush and mahogany were also highly similar. The greatest amount of exposed rock was also found in these two areas.

The flexibility of the various shrub populations to changes in the environment is shown in Table 1 . Needle-leaf mountain mahogany was restricted to the slickrock areas. Fourwing saltbush also was apparently limited in its ability to become established in areas best suited for other shrub species. Sagebrush dominated the mesa tops and was the most widely distributed shrub. The shrub species in the mixed-shrub community (cliff fendlerbush, cliffrose, and buffaloberry) occupied similar sites although areas existed where each was most abundant.

Analysis of the site characteristics in open areas adjacent to the shrubs allows for comparison of the different areas prior to shrub establishment (Table 2a). Soil texture did not vary significantly between shrub types. Average percent sand, silt, and clay was $83 \%, 12 \%$, and $5 \%$ respectively. The $\mathrm{pH}$ of the soil was lowest in areas near cliff fendlerbush, sagebrush, and mountain mahogany; intermediate for cliffrose and buffaloberry and most alkaline in areas adjacent to fourwing saltbush. Soil development varied significantly between the different sites. The deepest soil was found in fourwing saltbush and sagebrush areas and averaged 32 centimeters in depth. Sagebrush also grew in areas of shallow soils with an average depth of 10 centimeters.

Topographic position (Table 2) of the different species was represented by index values ranging from $1-3$. Drainage 


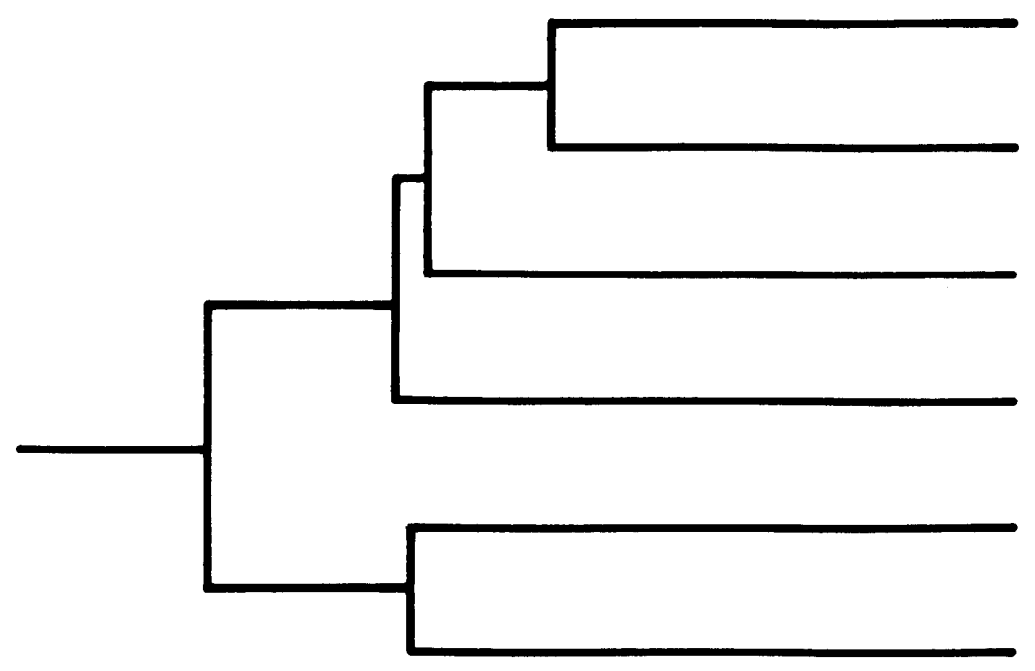

Fendlera rupicola

Shepherdia rotundifolia

Artemisia tridentata

Cowania mexicana

Atriplex canescens

Cercocarpus intricatus

Fig. 1. Similarity in understory composition of the six shrubs.

accumulation areas, midslope, and ridgetop areas correspond to values of 1,2 , and 3 respectively. Optimum habitat for sagebrush was on nearly level terrain while all other shrubs occupied midslope positions.

Slope aspect data was transformed according to Beers et al. (1966) to allow the use of aspect as an independent variable in statistical analysis of the six shrub habitats. Northeast aspects receive a value of 2.0 , the southwest a value of 0.0 , and intermediate aspects vary from 2.0 to 0.0 in both directions. The low index value for sagebrush $(0.60)$ indicates a more southwestern exposure than is the case for the other shrubs. Cliffrose had an intermediate value for aspect (1.21), while the remaining shrubs averaged 1.74.

Discriminate analysis (Klecka 1975) was used to determine if site characteristics of areas adjacent to shrubs had an influence in their distribution and possible establishment. Data on site characteristics from five plots were used to group each shrub habitat type. Based on these characteristics, $73 \%$ of the plots were classified correctly. The most important characteristic for grouping the six habitat types was percent slope, followed by soil depth, aspect, topographic position, $\mathrm{pH}$, and soluble salts. All of the fourwing saltbush plots were classified

Table 2. Site characteristics in open areas adjacent to shrubs (A) and beneath shrubs (B).

\begin{tabular}{|c|c|c|c|c|c|c|c|c|c|c|}
\hline \multirow[b]{2}{*}{ Shrubs } & \multicolumn{10}{|c|}{ Site characteristics } \\
\hline & $\begin{array}{l}\text { Sand } \\
(\%)\end{array}$ & $\begin{array}{l}\text { Silt } \\
(\%)\end{array}$ & $\begin{array}{l}\text { Clay } \\
(\%)\end{array}$ & $\begin{array}{l}\text { Fines } \\
(\%)\end{array}$ & $\mathrm{pH}^{a}$ & $\begin{array}{l}\text { Soluble }^{a} \\
\text { Salts } \\
\text { (ppm) }\end{array}$ & $\begin{array}{l}\text { Soil }^{a} \\
\text { depth } \\
(\mathrm{cm})\end{array}$ & $\begin{array}{l}\text { Slope } \\
(\%)\end{array}$ & Aspect & $\begin{array}{l}\text { Topographic } \\
\text { position }\end{array}$ \\
\hline \multicolumn{11}{|l|}{ A } \\
\hline Cliff fendlerbush & $82.8 a^{*}$ & $12.4 \mathrm{a}$ & $4.8 \mathrm{a}$ & $17.2 \mathrm{a}$ & $7.16 \mathrm{a}$ & $194.6 \mathrm{a}$ & $10.40 \mathrm{a}$ & $22.2 \mathrm{ab}$ & $1.92 \mathrm{a}$ & $1.80 \mathrm{a}$ \\
\hline Saltbush & $83.0 \mathrm{a}$ & $12.8 \mathrm{a}$ & $4.2 \mathrm{a}$ & $17.0 \mathrm{a}$ & $7.70 \mathrm{~b}$ & $167.4 \mathrm{a}$ & $25.80 \mathrm{~b}$ & $70.4 c$ & $1.65 \mathrm{a}$ & $2.00 \mathrm{a}$ \\
\hline Cliffrose & $82.8 \mathrm{a}$ & $12.4 a$ & $4.6 \mathrm{a}$ & $17.0 \mathrm{a}$ & $7.46 \mathrm{ab}$ & $160.2 \mathrm{a}$ & $8.40 \mathrm{a}$ & $31.8 \mathrm{ab}$ & $1.21 \mathrm{ab}$ & $2.20 \mathrm{a}$ \\
\hline Buffaloberry & $81.8 \mathrm{a}$ & $12.8 \mathrm{a}$ & $5.4 \mathrm{a}$ & $18.2 \mathrm{a}$ & 7.42ab & $185.6 \mathrm{a}$ & $10.80 \mathrm{a}$ & $39.2 \mathrm{bc}$ & $1.79 \mathrm{a}$ & $2.00 \mathrm{a}$ \\
\hline Sagebrush & $84.8 \mathrm{a}$ & $10.4 \mathrm{a}$ & $4.8 \mathrm{a}$ & $15.2 \mathrm{a}$ & $7.08 \mathrm{a}$ & $145.6 \mathrm{a}$ & $37.80 \mathrm{~b}$ & $16.40 \mathrm{a}$ & $.60 \mathrm{~b}$ & $2.80 \mathrm{~b}$ \\
\hline Mahogany & $85.4 \mathrm{a}$ & $9.8 \mathrm{a}$ & $4.8 \mathrm{a}$ & $14.6 \mathrm{a}$ & $7.18 \mathrm{a}$ & $136.0 \mathrm{a}$ & $10.58 \mathrm{a}$ & $29.90 \mathrm{ab}$ & $1.63 \mathrm{a}$ & $2.00 \mathrm{a}$ \\
\hline Average & 83.4 & 11.8 & 4.8 & 16.6 & 7.33 & 164.9 & 17.3 & 35.0 & 1.47 & 2.10 \\
\hline \multicolumn{11}{|l|}{$\mathbf{B}$} \\
\hline Cliff fendlerbush & $81.8 \mathrm{a}$ & $14.2 \mathrm{a}$ & $4.0 \mathrm{bcc}$ & $18.2 \mathrm{a}$ & $7.46 \mathrm{ab}$ & 269.0ab & $26.4 a$ & $22.2 \mathrm{ab}$ & $1.92 \mathrm{a}$ & $1.80 \mathrm{a}$ \\
\hline Saltbush & $82.4 \mathrm{a}$ & $13.2 \mathrm{a}$ & $4.4 \mathrm{ab}$ & $17.6 \mathrm{a}$ & $7.84 \mathrm{c}$ & $327.0 \mathrm{a}$ & $60.0 c$ & $70.4 c$ & $1.65 \mathrm{a}$ & $2.00 \mathrm{a}$ \\
\hline Cliffrose & $81.6 a$ & $13.6 \mathrm{a}$ & $4.8 \mathrm{ab}$ & $18.4 \mathrm{a}$ & $7.70 \mathrm{bc}$ & $190.8 \mathrm{bc}$ & $17.8 \mathrm{a}$ & 31.8ab & $1.21 \mathrm{ab}$ & $2.20 \mathrm{a}$ \\
\hline Buffaloberry & $79.4 \mathrm{a}$ & $14.8 \mathrm{a}$ & $5.8 \mathrm{a}$ & $20.6 a$ & $7.46 \mathrm{ab}$ & $216.8 \mathrm{abc}$ & $23.6 \mathrm{a}$ & $39.2 \mathrm{bc}$ & $1.79 \mathrm{a}$ & $2.00 \mathrm{a}$ \\
\hline Sagebrush & $82.4 a$ & $12.4 \mathrm{a}$ & $5.2 \mathrm{ab}$ & $17.6 \mathrm{a}$ & $7.34 \mathrm{a}$ & $126.6 \mathrm{c}$ & $45.2 b$ & $16.4 \mathrm{a}$ & $.60 \mathrm{~b}$ & $2.80 \mathrm{~b}$ \\
\hline Mahogany & $88.6 b$ & $8.4 a$ & $2.8 \mathrm{c}$ & $11.4 \mathrm{~b}$ & $7.50 \mathrm{ab}$ & $130.6 \mathrm{c}$ & $23.0 \mathrm{a}$ & 29.9ab & $1.63 \mathrm{a}$ & $2.00 \mathrm{a}$ \\
\hline Average & 82.7 & 12.8 & 4.5 & 17.3 & 7.54 & 210.1 & 32.7 & 35.0 & 1.47 & 2.10 \\
\hline
\end{tabular}

\footnotetext{
a Average values for these characteristics differ significantly $(0.5$ level) under and between shrubs.
}

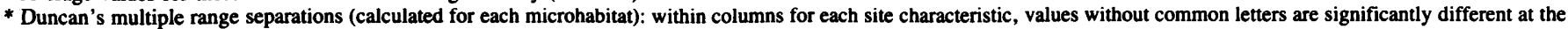
5\% level. 
correctly indicating that unique habitats exist for saltbush establishment. Eighty percent of the sagebrush and mountain mahogany plots, and $60 \%$ of those for cliff fendlerbush, cliffrose, and buffaloberry were classified correctly. The use of discriminate analysis showed that the habitats of shrubs of the mixed-brush zone were less distinctive than those of the other shrubs.

Data presented in Table $2 b$ indicate that shrubs exert a varied influence on their immediate surroundings. With respect to soil texture, areas under mountain mahogany had significantly more sand and less clay in the soil than soils under other shrubs. Mountain mahogany pioneers newly established soils of the slickrock areas. When percent fines (clay plus silt) of the different habitat types are compared, it is evident that the extent of soil development in mountain mahogany areas was less than in areas occupied by the other shrubs.

Shrubs also seem to affect $\mathrm{pH}$ of the soil in a different manncr. Average values ranged from 7.3 to 7.8 for sagebrush and fourwing saltbush respectively. Due to the sample variation, it was difficult to show statistical differences but it appears that patterns do exist. For example, sagebrush showed the lowest $\mathrm{pH}$ values while cliff fender bush, buffaloberry, and mountain mahogany had intermediate values. Four wing saltbush and cliffrose showed the highest values.

The larger concentration of total soluble salts beneath the canopy of cliff fendlerbush and fourwing saltbush differed significantly from low values for sagebrush and mountain mahogany dominated soils. The value for cliffrose was similar to that of fourwing saltbush and cliff fendlerbush, whereas buffaloberry was quite variable in salt concentration and not significantly different from any of the shrubs. A comparison of soil depth under the shrubs shows the deepest soil existed beneath fourwing saltbush, sagebrush being intermediate, and the least depth found under the other shrubs.

When site characteristics for the microenvironment beneath shrubs were used to group different shrub types using discriminant analysis (Klecka 1975), 93\% of the grouped cases were correctly classified. This compared with a $73 \%$ correct classification for the same plots using site characteristics of open areas adjacent to the shrubs. Soil depth was the most important factor used to classify different microhabitats beneath the shrubs. Other characteristics, in descending order of importance, were: percent slope, percent clay, topographic position, aspect, and soil $\mathrm{pH}$. The microenvironments beneath cliff fendlerbush, fourwing saltbush, cliffrose, and sagebrush were very distinct. Eighty percent of the mountain mahogany plots were also correctly classified with one plot being grouped with buffalobcrry. Such evidence indicates that the shrubs influence the general soil characteristics beneath the canopy.

Results of analyses of mineral composition of soils from open areas adjacent to shrubs are provided in Table $3 \mathrm{a}$ and are intended to give some idea as to the characteristics of the soil prior to shrub establishment. Of the ten nutrients analyzed from soils sampled between shrubs, the concentration of calcium, potassium, iron, and manganese varied significantly between the six habitats. Calcium was the most concentrated nutrient and was most abundant in the fourwing saltbush and buffaloberry sites. Potassium was also found in greater concentration in these areas. Buffaloberry and sagebrush sites exhibited the greatest concentration of iron. Buffaloberry sites were also high in manganese. Mountain mahogany-dominated areas were consistently low in soil minerals. The macronutrients magnesium, phosphorus, and nitrogen were uniformly distributed as were the micronutrients zinc and copper. When mineral composition in the soil between the shrubs was used to classify different habitat types, $70 \%$ of the plots were correctly classified by discriminant analysis (Klecka 1975). It appears that different habitats open to shrub establishment vary with respect to both site characteristics and mineral composition. Eighty percent of the cliffrose, sagebrush, and mahogany plots were correctly classified. Soil mineral composition in areas between these shrubs was fairly distinct. Only $60 \%$ of cliff fendlerbush, fourwing saltbush, and buffaloberry were classified correctly. The soil mineral composition of these habitat was not as characteristic. Elements most useful in classification of different shrub types were sodium, calcium, iron, copper, nitrogen, and phosphorus.

Mineral composition of the soil beneath the shrubs also varied between different habitats (Table $3 b$ ). Calcium was most concentrated under buffaloberry and fourwing saltbush and least concentrated under sagebrush and mahogany.

Table 3. Soil mineral concentrations (ppm) in open areas adjacent to shrubs (A) and beneath shrubs (B).

\begin{tabular}{|c|c|c|c|c|c|c|c|c|c|c|}
\hline Shrubs & $\mathrm{N}^{z}$ & $\mathbf{P}^{2}$ & $\mathrm{Ca}$ & $\mathbf{M g}^{\mathbf{z}}$ & $\mathrm{K}^{2}$ & $\mathrm{Na}^{z}$ & $\mathrm{Zn}$ & $\mathrm{Fe}$ & Mn & $\mathrm{Cu}$ \\
\hline \multicolumn{11}{|l|}{$\mathbf{A}$} \\
\hline Cliff fendlerbush & $236.6 a^{* *}$ & $5.24 \mathrm{a}$ & $2008.8 \mathrm{a}$ & $658.8 \mathrm{a}$ & $79.8 b$ & $9.6 \mathrm{a}$ & $1.29 \mathrm{a}$ & $4.27 \mathrm{a}$ & $3.94 b c$ & $0.50 \mathrm{a}$ \\
\hline Saltbush & $324.4 a$ & $5.70 \mathrm{a}$ & $3646.2 b$ & $368.8 \mathrm{a}$ & $101.9 \mathrm{a}$ & $9.6 \mathrm{a}$ & $1.50 \mathrm{a}$ & $3.26 \mathrm{a}$ & $5.22 \mathrm{ac}$ & $0.40 \mathrm{a}$ \\
\hline Cliffrose & $369.8 \mathrm{a}$ & $7.84 a$ & $1700.0 \mathrm{a}$ & $507.5 a$ & $66.8 \mathrm{~b}$ & $6.6 \mathrm{a}$ & 1.13 & $3.44 \mathrm{a}$ & $3.03 \mathrm{bc}$ & $0.48 \mathrm{a}$ \\
\hline Buffaloberry & $492.8 \mathrm{a}$ & $8.98 a$ & $2982.5 b$ & $556.2 \mathrm{a}$ & $103.6 \mathrm{a}$ & $9.7 \mathrm{a}$ & $1.50 \mathrm{a}$ & $6.02 \mathrm{ab}$ & $6.08 a$ & $0.44 a$ \\
\hline Sagebrush & $335.0 \mathrm{a}$ & $4.60 \mathrm{a}$ & $1515.0 \mathrm{a}$ & $608.8 \mathrm{a}$ & $75.0 \mathrm{~b}$ & $8.4 \mathrm{a}$ & $1.09 \mathrm{a}$ & $6.31 \mathrm{~b}$ & $4.22 \mathrm{abc}$ & $0.46 a$ \\
\hline Mahogany & $327.0 \mathrm{a}$ & $7.14 a$ & $1675.0 \mathrm{a}$ & $548.8 \mathrm{a}$ & $52.8 b$ & $9.4 \mathrm{a}$ & $1.18 \mathrm{a}$ & $3.35 \mathrm{a}$ & $2.32 \mathrm{~b}$ & $0.38 \mathrm{a}$ \\
\hline Average & 347.4 & 6.58 & 2254.6 & 541.5 & 80.0 & 8.9 & 1.28 & 4.44 & 4.14 & 0.44 \\
\hline \multicolumn{11}{|l|}{ B } \\
\hline Cliff fendlerbush & $478.8 \mathrm{a}$ & $9.10 \mathrm{a}$ & $2150.0 \mathrm{bc}$ & $653.8 \mathrm{a}$ & $142.2 \mathrm{a}$ & $7.9 \mathrm{a}$ & $1.24 \mathrm{a}$ & $5.41 \mathrm{a}$ & $4.83 \mathrm{a}$ & $0.50 \mathrm{a}$ \\
\hline Saltbush & $545.0 \mathrm{a}$ & $5.74 a$ & $3690.0 \mathrm{ac}$ & $938.8 b$ & $502.5 b$ & $9.7 \mathrm{~b}$ & $1.54 \mathrm{a}$ & $3.71 \mathrm{a}$ & $7.69 \mathrm{a}$ & $0.42 \mathrm{a}$ \\
\hline Cliffrose & $683.6 \mathrm{a}$ & $10.50 \mathrm{a}$ & $2357.5 b c$ & $638.8 \mathrm{a}$ & $115.9 \mathrm{a}$ & $7.7 \mathrm{a}$ & $1.63 \mathrm{a}$ & $4.70 a$ & $4.33 \mathrm{a}$ & $0.46 a$ \\
\hline Buffaloberry & $587.4 \mathrm{a}$ & $14.28 \mathrm{a}$ & $4905.0 \mathrm{a}$ & $783.8 \mathrm{ab}$ & $153.1 \mathrm{a}$ & $8.1 \mathrm{a}$ & $1.63 a$ & $7.68 \mathrm{a}$ & $7.11 \mathrm{a}$ & $0.55 a$ \\
\hline Sagebrush & $559.6 \mathrm{a}$ & $6.46 \mathrm{a}$ & $1740.0 \mathrm{~b}$ & $682.5 \mathrm{ab}$ & $101.7 \mathrm{a}$ & $9.7 \mathrm{~b}$ & $1.22 \mathrm{a}$ & $7.17 \mathrm{a}$ & $4.16 a$ & $0.47 a$ \\
\hline Mahogany & $540.4 a$ & $9.16 \mathrm{a}$ & $1650.0 \mathrm{~b}$ & $530.0 \mathrm{a}$ & $82.5 \mathrm{a}$ & $7.9 \mathrm{a}$ & $1.22 \mathrm{a}$ & $4.71 \mathrm{a}$ & $3.38 \mathrm{a}$ & $0.30 \mathrm{a}$ \\
\hline Average & 565.8 & 9.21 & 2748.8 & 704.6 & 183.0 & 8.5 & 1.41 & 5.56 & 5.25 & 0.45 \\
\hline
\end{tabular}

${ }^{z}$ Average values for these characteristics differ significantly (.05 level) under and between shrubs.

* Duncan's multiple range separations (calculated for each microhabitat): within columns for each mineral, values without common letters are significantly different at the $5 \%$ level. 
Table 4. Elemental content of current year's growth of six shrubs expressed in micrograms per grams of plant material (ppm).

\begin{tabular}{|c|c|c|c|c|c|c|c|c|c|c|}
\hline \multirow[b]{2}{*}{ Shrub } & \multicolumn{10}{|c|}{ Elements } \\
\hline & $\mathbf{N}$ & $\mathbf{P}$ & $\mathrm{Ca}$ & $\mathbf{M g}$ & $\mathbf{K}$ & $\mathrm{Na}$ & $\mathrm{Zn}$ & $\mathrm{Fe}$ & $\mathrm{Mn}$ & $\mathrm{Cu}$ \\
\hline Cliff fendlerbush & 6810 & 898 & 5430 & 1012 & 9865 & 312 & 19.2 & 147 & 15.5 & 6.2 \\
\hline Saltbush & 12940 & 642 & 8200 & 2025 & 16150 & 350 & 6.0 & 115.5 & 30.0 & 6.0 \\
\hline Cliffrose & 10360 & 634 & 9325 & 1225 & 3440 & 250 & 18.8 & 75.8 & 9.0 & 7.0 \\
\hline Buffaloberry & 13125 & 1018 & 8040 & 1188 & 6915 & 275 & 16.8 & 137.5 & 24.0 & 5.5 \\
\hline Sagebrush & 8315 & 975 & 4465 & 950 & 11640 & 375 & 26.5 & 186.0 & 27.8 & 8.8 \\
\hline Mahogany & 7990 & 698 & 8265 & 962 & 2830 & 238 & 20.5 & 93.2 & 22.2 & 6.7 \\
\hline Average & 9923 & 811 & 7288 & 1227 & 8473 & 300 & 17.9 & 125.8 & 21.4 & 6.7 \\
\hline
\end{tabular}

Potassium was highly concentrated beneath the canopy of fourwing saltbush and was lowest beneath mountain mahogany. The concentration of potassium beneath other shrubs was intermediate. Cliff fendlerbush, cliffrose, and mountain mahogany.influenced soils were lowest in magnesium and significantly different from the soils influenced by fourwing saltbush. Buffaloberry and sagebrush-influenced soils were intermediate in magnesium concentrations. Sodium was most abundant beneath fourwing saltbush and sagebrush and did not differ significantly among the other shrubs. Phosphorus and nitrogen were uniformly distributed underneath the shrubs as were all the micronutrients except sodium.

Seventy-seven percent of the plots were correctly classified when mineral composition beneath shrubs was used as the basis for classification. Soil mineral composition beneath buffaloberry shrubs was highly characteristic: and allowed all plots to be correctly classified. Eighty percent of cliff fendlerbush, fourwing saltbush, sagebrush, and mahogany plots were classified correctly, indicating that these shrubs alter the soil mineral composition in unique ways. Soil mineral composition beneath cliffrose was highly variable and resembled that of cliff fendlerbush, fourwing saltbush, and sagebrush. Eighty percent of the plots were correctly classified when soils between cliffrose shrubs were classified, but when the soil mineral composition beneath the shrub canopy was used to group the shrubs only $40 \%$ of the cliffrose plots were correctly classified. Cliffrose did alter the soil mineral characteristics of its environment, but did so in a manner highly similar to several other shrubs.

The mineral composition of the current year's growth for each shrub is outlined in Table 4. Unfortunately, not enough plant material was collected from each shrub to provide independent samples for analysis. As a result, statistical analysis of the data is not justified, although mean values are important and represent averages of two composite samples derived from the ten plants sampled per shrub species Information provided in Table 4 further shows that minerals were not absorbed in the same proportion as found in the soil. As expected, the macronutrients nitrogen, potassium, calcium, magnesium, and phosphorus were concentrated in the leaves and twigs to a greater degree than that of the micronutrients sodium, zinc, iron, manganese, and copper. When compared to the concentrations found to be adequate for higher plants, the concentration of nitrogen, potassium, and manganese appcared to be slightly deficient (Epstein 1972).

\section{Discussion}

It has been shown that different species of shrubs have a varied influence on the soil chemistry of their environment. If the influence of shrubs on various parameters of the soil surface is compared with the characteristics of the soil prior to shrub establishment, several trends become apparent.

The concentration of total soluble salts under the shrub canopy was significantly greater than that of open areas adjacent to shrubs (Table 2). Sharma and Tongway (1973) and Charley and West (1975) also found this to be the case. Salts are absorbed throughout the rooting volume of the plant and accumulate in the surface layer beneath the shrubs.

The concentration of total soluble salts in the soil of areas not influenced by a shrub canopy did not differ significantly. However, the six shrubs did differ as to their impact on the concentration of salts in the soil. Sagebrush and mountain mahogany had an insignificant affect on the accumulation of soil salts. Saltbush and cliff fenderbush showed a greater impact on soil salinity in that the soluble salts in the soil beneath their canopies were generally much higher.

The soil $\mathrm{pH}$ under the shrub canopy was significantly greater than that of adjacent open areas (Table 2). Although the margin of difference was not great, little variation was found under and between shrubs. Sharma and Tongway (1973) and Greenwood and Brotherson (1978) have reported an increase in $\mathrm{pH}$ under shrubs, whereas Charley and West (1975) found that such differences were not always predictable.

Soil depth beneath shrubs and that found in open areas adjacent to shrubs was shown to be significantly different and might be attributed to shrub influence. However, soil depth between the different shrubs is not so easily explained. For example, soil depth in the mixed shrub zone and slickrock areas was relatively shallow when compared to soil depths beneath saltbush and sagebrush. Saltbush was found growing in areas of greatest soil depth. These differences are more likely due to genetic variations in the shrubs themselves than in their effects on soil accumulation beneath their canopies.

It was possible to rank the six shrubs according to the variation in concentration of calcium, magnesium, potassium and sodium in the soil beneath them. The concentration of a particular mineral was classified as high, intermediate, or low for each shrub and assigned values of 3,2, and 1 respectively. Theoretically, a species could receive a value of 12 if the concentration of the four minerals were always among the highest group.

We should note that of the minerals that did differ significantly under the shrubs, the greatest concentrations were consistently found under fourwing saltbush (Table 5). Saltbush grew in the deepest soils and the greater rooting volume might account for more extensive redistribution of minerals from other zones. The species is also equipped with salt glands to facilitate the removal of excess minerals.

Buffaloberry was ranked second, although the depth of the soil underneath the canopy did not differ from the other shrubs of the mixed-brush zone. It has been postulated that leaf size might account for some of the variation in the soil mineral composition beneath shrubs (Sharma and Tongway 1973). It is 
Table 5. Ranking of six shrubs according to extent of mineral enrichment (calcium, magnesium potassium, and sodium) beneath shrub canopy. The concentration of a particular mineral was classified as high, intermediate or low for each shrub and assigned a value of 3, 2, or 1 respectively. Theoretically, a species could receive a value of 12 if the concentration of the minerals were aways among the highest group.

\begin{tabular}{lcccc}
\hline \hline Shrub & High & Intermediate & Low & Total \\
\hline Saltbush & $3^{a}$ & 1 & 0 & $11^{b}$ \\
Buffaloberry & 1 & 2 & 1 & 8 \\
Sagebrush & 1 & 1 & 2 & 7 \\
Cliff fendlerbush & 0 & 2 & 2 & 6 \\
Cliffrose & 0 & 1 & 3 & 5 \\
Mahogany & 0 & 0 & 4 & 4 \\
\hline
\end{tabular}

${ }^{a}$ Numbers indicate that of the four minerals, three were among the highest concentrations.

${ }^{b}$ Number was derived when 3 of the 4 minerals were among the highest concentrations and one way among the intermediate concentrations (i.e. $3 \times 3=9$ and $1 \times 2=2$ thus 9 plus 2 equal 11)

interesting to note that buffaloberry had the largest leaf of all the shrubs studied.

Sagebrush, cliffrose, and cliff fendlerbush all had similar sized leaves, although the greater soil depth under sagebrush may account for the difference in mineral accumulation. Mountain mahogany had the smallest leaves of all the shrubs and was found in shallow soils and cracks in the sandstone.

Of special interest was the percent increase in nitrogen, phosphorus, potassium, and magnesium in soils under shrubs compared to soils adjacent to shrubs. Magnesium was also highly concentrated under the shrubs. Since potassium and magnesium were the only macronutrients that function as cofactors of plant enzymes, it is possible that the shrubs recycle more of these cations as a result of their inefficiency in enzyme systems (Epstein 1972).

Nitrogen was also highly concentrated under shrubs. Charley and West (1975) and Garcia-Moya and McKell (1970) reported nitrogen accumulation under shrubs and an associated concentration decline in the surround environment. Charley (1977) suggested the possibility of this also being attributed to an increase in nitrogen fixation by free living microorganisms in and under litter mats, animal activity, and canopy capture of wind transported soils.

The concentration of phosphorus was found to be significantly greater in soils under shrubs. Organic matter accumulation under shrubs probably accounted for the increase. Charley and West (1975) found greatest differences in the concentration of organic phosphorus and also found differences in available phosphorus under and between shrubs. Average values of all minerals were shown to be greater under shrubs, but too much variation was found in the samples to prove statistical differences.

Mineral concentration of plant materials versus that of the soil serves to show the extent that minerals are concentrated in the plants. Although mineral composition of the soil differed between the six shrubs, the plants were fairly consistent in their ability to accumulate minerals. On the average, shrubs concentrated phosphorus about 110 times that found in the soil. The concentration of phosphorus found in the soil was far below the $200 \mathrm{ppm}$ suggested by Epstein (1972) as being adequate for maintenance of healthy plant tissue.

Potassium was 68 times more concentrated in plant tissue than in the soil surface. According to Epstein (1972), plants have evolved a mechanism for high accumulation of potassium from the soil to allow for the inefficiency of potassium as a cofactor in enzyme systems. Potassium is the only monovalent
Table 6. Comparison of the mineral composition of shrubs.

\begin{tabular}{lcrrrrr}
\hline & \multicolumn{6}{c}{ Elemental concentration $(\%)$} \\
\cline { 2 - 7 } Species & $\mathbf{H}$ & \multicolumn{1}{c}{$\mathbf{P}$} & \multicolumn{1}{c}{$\mathrm{M}$} & \multicolumn{1}{c}{$\mathrm{Na}$} & \multicolumn{1}{c}{$\mathrm{Ca}$} & \multicolumn{1}{c}{$\mathrm{Mg}$} \\
\hline Atriplex confertifolia & 1.66 & .07 & 1.84 & 5.75 & 2.69 & .77 \\
Atriplex canescens & 1.74 & 1.38 & 2.88 & .16 & 2.57 & 1.23 \\
Larrea divaricata & 1.86 & .15 & 2.20 & .03 & .68 & .13 \\
Lycium pallidum & 1.97 & .08 & 2.41 & 1.49 & 2.46 & 1.05 \\
Grayia spinosa & 1.67 & .05 & 4.29 & .52 & 1.67 & 1.19 \\
Ceratoides lanata & & .22 & 3.24 & .05 & 1.43 & .49 \\
Franseria dumosa & & .48 & 4.78 & .10 & 2.49 & .59 \\
Artemisia tridentata & 1.24 & .19 & .95 & .09 & 1.02 & .40 \\
Atriplex inflata & 3.10 & .28 & 3.20 & 5.90 & 1.40 & 2.10 \\
Atriplex vesicaria & 2.50 & .15 & 3.90 & 6.50 & 1.20 & \\
Kochia sedifolia & 2.06 & .11 & 2.80 & 7.60 & 1.32 & .81 \\
Acacia aneura & 2.14 & .08 & .68 & .13 & 1.47 & .51 \\
Coleogyne ramossissima & 1.94 & .17 & 1.42 & .07 & 2.23 & .41 \\
Average* & 1.99 & .26 & 2.66 & 2.18 & 1.74 & .81 \\
Cercocarpus montanus & .90 & .07 & .31 & .04 & .55 & .26 \\
Juniperus osteosperma & .77 & .05 & .35 & .03 & 1.45 & .15 \\
Average & .84 & .06 & .33 & .04 & 1.00 & .21 \\
Average of six shrubs & 1.16 & .09 & .99 & .04 & .85 & 1.4 \\
from this study & & & & & & \\
\hline
\end{tabular}

* Charley, J.L., (1977)

${ }^{+}$Osayande, S. (Unpublished M.S. thesis)

cation essential for all higher plants. Arid regions are often characterized by having a greater concentration of potassium in the plant (Epstein 1972). In this study, potassium was found in greater concentration than sodium in both the soils and in the plant material

When compared to soil mineral concentration, calcium and magnesium were the least concentrated nutrients in the tissue of the shrubs. Their relatively high concentration in soils compared to those values determined by Epstein (1972) as being adequate for higher plants may account for the lower values.

Calcium to phosphorus ratios that are close to 2.0 are considered optimum for the nutritional needs of most animals, although there is evidence that suggests that ruminants can tolerate higher ratios (McDonald et al. 1973). Mule deer (Odocoileus hemionus) are found in the monument and, since they feed almost exclusively on shrubs during the winter, the balance of these minerals in the diet is important. The most satisfactory calcium to phosphorus ratios were found in the leaves and twigs of sagebrush, cliff fendlerbush, and buffaloberry with values of $4.58,6.05$, and 7.90 respectively. Cliffrose had the highest ratio, 14.71, and was followed by fourwing saltbush (12.77) and mountain mahogany (11.84). The concentration of calcium and phosphorus in leaves and stems was negatively correlated with an $r$ value of 0.67 .

The average potassium to calcium ratio for the plant material from the six shrubs was 1.33 and compared favorably with the value of 1.4 for shrubs in a study by Harner and Harper (1973). In their study, the ratio for shrubs was lower than that for forbs and grasses. They suggested that the low values for shrubs was related to root cation exchange properties. Dicot roots were found to be more negatively charged than monocot roots and were expected to compete more effectively for divalent cations. The variation in potassium to calcium ratios among the shrubs in this study might also be attributed to root cation exchange capacity. Cliff fendlerbush, fourwing saltbush, and sagebush had high values and averaged 2.13, whereas cliffrose, buffaloberry and mountain mahogany averaged 0.52 .

The mineral composition of shrubs from various studies are compared with the results from this study in Table 6. It is 
evident that the mineral composition of shrubs varies among species and individuals on rangelands. The large discrepancies found in mineral composition between the shrubs in this study and those from other studies may be due in part to the fact that in arid rangelands, yearly and seasonal variations in mineral cycling is highly dependent upon the amount, kind, and distribution of rainfall. This variation is partly responsible for the heterogeneous patterning of minerals in a rangeland ecosystem since soil mineral composition beneath shrubs is mostly affected by retention of litter fall, shrub age, and specific chemical composition of inorganic residues (Charley 1977).

\section{Literature Cited}

Beers, T.W., P.E. Dress, and L.C. Wensel. 1966. Aspect transformation in site productivity research. J. Forestry 64:691-692.

Bouycoucos, G.J. 1951. A recalibration of the hydrometer method for making mechanical analysis of soils. J. Agron. 43:434-438.

Charley, J.L. 1972. The role of shrubs in nutrient cycling, p. 182-203. In: C.M. McKell, J.P. Blaisdell, and J.R. Goodin (eds.) Wildland shrubstheir biology and utilization. U.S. Forest Dep. Agr. Serv. Gen. Tech. Rep. INT-1.

Charley, J.L. 1977. Mineral cycling in rangeland ecosystems, p. 216-256. In: R.E. Sosebee (ed.), Rangeland plant physiology. Society for Range Management Range Science Series No. 4.

Charley, J.L., and N.E. West. 1974. Plant-induced soil chemical patterns in some desert shrub-dominated ecosystem of Utah. U. Ecol. 63:945964.

Epstein E. 1972. Mineral Nutrition of Plants: Principles and Perspectives. John Wiley and Sons, Inc., New York. 412 p.

Fireman, M., and H.E. Hayward. 1952. Indicator significance of some shrubs in the Escalante desert Utah. Bot. Gaz. 114:143-155.
Garcia-Moya, E., and C.M. McKell. 1970. Contribution of shrubs to the nitrogen economy of a desert-wash plant community. Ecology 51:81-88.

Greenwood, L.C., and J.D. Brotherson. 1978. Some ecological relationships between pinyon-juniper and birchleaf mountain mahogany stands. J. Range Manage. 31:164-168.

Harner, R.F. and K.T. Harper. 1973. Mineral Composition of grassland species of the eastern Great Basin in relation to stand productivity. Can. J. Bot. 51:2037-2046.

Jackson, M.L. 1958. Soil Chemicals Analysis. Prentice-Hall, Inc., Englewood Cliffs, New Jersey. 498 p.

Klecka, W.R. 1975. Discriminant analysis, p 434-467. In: Nie, N.H., C.H. Hull, J.G. Jenkins, K. Steinbrenner, and D.H. Bent. Statistical Package for the Social Sciences, second edition. McGraw-Hill Book Company, New York, N.Y. 675 p.

McDonald, P.R., R.A. Edwards, and J.F.D. Greenhalgh. 1973. Animal Nutrition. Longman Inc., New York, N.Y. 479 p.

Osayande, S.T.O. 1978. Concentrations of minerals in true mountain mahogany and Utah juniper and in the soils on which they grow. Unpublished M.S. thesis, Brigham Young University, Provo, Utah. 19 p.

Rickard, W.H., and R.F. Keough. 1968. Soil plant relationships of two steppe desert shrubs. Plant and Soil 29:205-213.

Rickard, W.H., J.F. Cline, and R.O. Gilbert. 1973. Soil beneath shrub halophytes and its influence upon the growth of cheatgrass. Northwest Sci. 47:213-217.

Russell, D.A. 1948. A Laboratory Manual for Soil Fertility Students, third edition. Wm. Brown. Co., Dubuque, lowa. $56 \mathrm{p}$.

Sharma, M.L., and D.J. Tongway. 1973. Plant induced soil salinity patterns in two saltbush (Atriplex sp.) communities. J. Range Manage. 26:121125.

Sneath, P.H.A., and R.R. Sokal. 1973. Numerical Taxonomy, the Principles and Practice of Numerical Classification. W.H. Freeman and Company, San Francisco, Calif. 547 p.

Tiedemann, A.R., and J.O. Klemmedson. 1973. Nutrient availability in desert grassland soils under mesquite (Prosopis juliflora) trees and adjacent open areas. Soil Sci. Soc. Amer., Proc. 37:107-111.

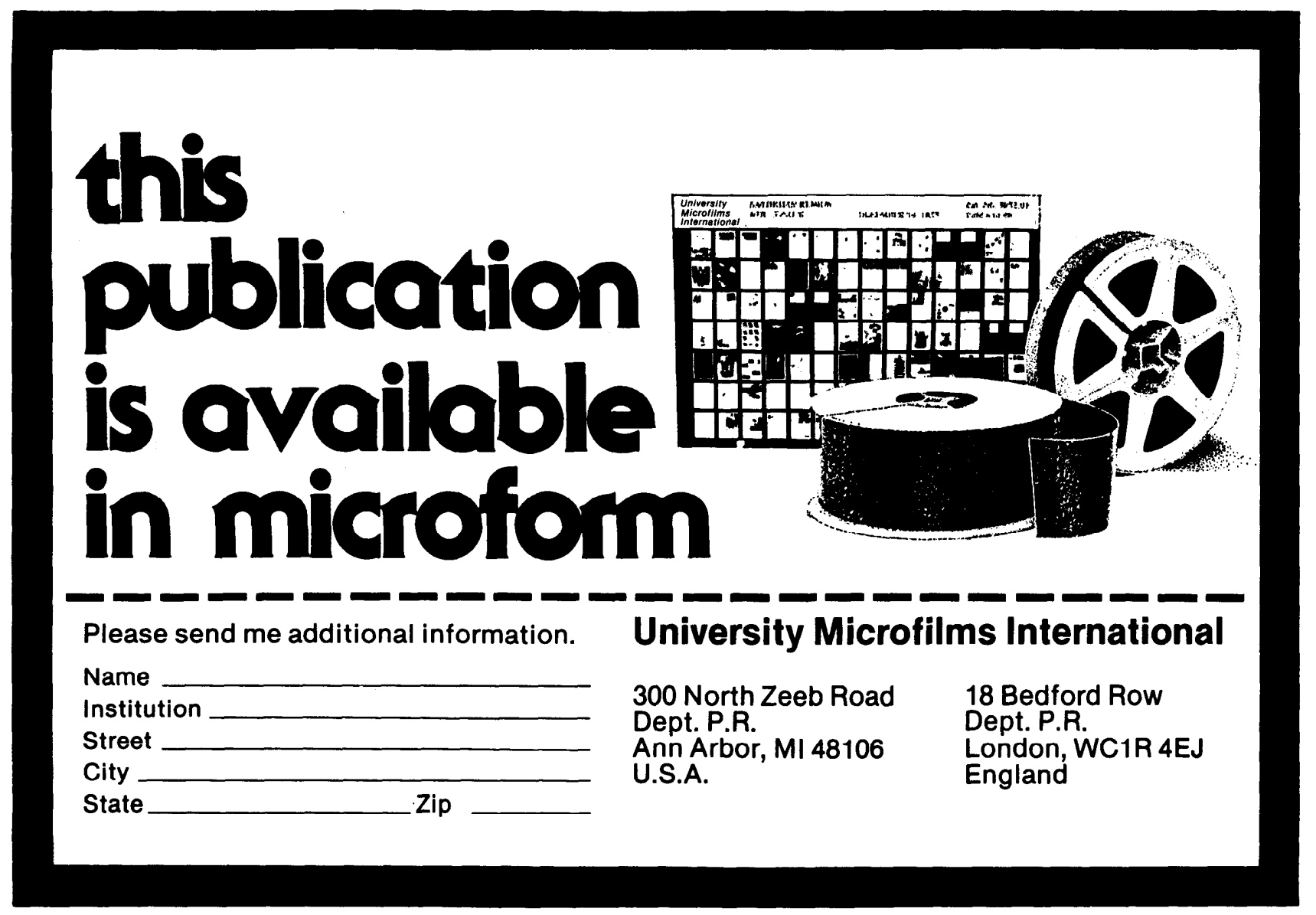

